Zhang Zhenhui

Instytut Badań Literatury Zagranicznej,

Chińska Akademia Nauk Społecznych w Pekinie

\title{
Literatura polska w Chinach i wymiana kulturalna między Polską a Chinami. Zapiski tłumacza
}

Recepcja literatury polskiej rozpoczęła się w Chinach na początku Xx wieku. Polska była wówczas jeszcze pod zaborami, a Chiny także doświadczały agresji kolonialnej ze strony państw zachodnich, co zbliżało perspektywę chińską do polskiej.

Znakomity chiński pisarz Lu Xun jako pierwszy zajął się tłumaczeniem i badaniem twórczości najsławniejszego polskiego poety Adama Mickiewicza. Lu Xun nazywał Mickiewicza poetą zemsty i wyzwolenia. Uważał, że Chinom taki właśnie poeta jest potrzebny [Lu Xun 1982]. Dlatego przetłumaczył na język chiński wybrane wiersze autora Pana Tadeusza oraz pisał o jego biografii i twórczości. Zajmował się również twórczością Juliusza Słowackiego, Zygmunta Krasińskiego oraz Henryka Sienkiewicza. Szczególnie cenił powieści historyczne tego ostatniego. Quo vadis zostało przetłumaczone na język chiński już w latach 30. xx wieku. Powieść ta cieszyła się wielką popularnością wśród chińskich czytelników'.

Już w roku 1949 - a więc wkrótce po proklamacji - Chińska Republika Ludowa nawiązała stosunki dyplomatyczne z Polską.

1 O inspiracjach Sienkiewiczowskich u Lu Xuna i innych autorów chińskich oraz recepcji twórczości Henryka Sienkiewicza w Chinach pisała m.in. Yi Lijun [2010]. 
Kolejne dziesięciolecia przyniosły liczne przekłady poezji Adama Mickiewicza oraz opowiadań Henryka Sienkiewicza, Bolesława Prusa, Elizy Orzeszkowej, Marii Konopnickiej, Stefana Żeromskiego, Władysława Reymonta. Ponadto ukazały się w języku chińskim powieści: Nad Niemnem Orzeszkowej, Pamiątka z celulozy Igora Newerlego, a nawet niektóre powieści produkcyjne z lat 50. Dzięki temu wzrosła znacząco znajomość polskiej literatury wśród chińskich czytelników².

Od końca lat 70. xx wieku, czyli od czasu wprowadzenia polityki reformy i otwarcia w naszym kraju, nastąpiła dalsza intensyfikacja kontaktów z Polską. Rozpoczął się rozwój wymiany kulturalnej między oboma krajami, wzrosła też znacznie liczba przekładów literatury polskiej na język chiński. Do dziś przetłumaczono m.in.: Pana Tadeusza i Dziady Adama Mickiewicza, poezję Juliusza Słowackiego i Cypriana Kamila Norwida, Krzyżaków oraz Trylogię Sienkiewicza, Lalkę i Faraona Bolesława Prusa, Ziemię obiecana i Chłopów Władysława Reymonta, Wierna rzekę i Popioły Stefana Żeromskiego, Stawę i chwate Jarosława Iwaszkiewicza, Ferdydurke Witolda Gombrowicza, powieści Olgi Tokarczuk. Ukazało się też wiele przekładów polskiej poezji, w tym wiersze Czesława Miłosza, Wisławy Szymborskiej, Tadeusza Różewicza, Zbigniewa Herberta, Adama Zagajewskiego. Cieszą się one ogromnym uznaniem wśród czytelników chińskich ${ }^{3}$.

W XxI wieku do Chin zaczęło przyjeżdżać wielu polskich artystów: muzyków, piosenkarzy i aktorów, którzy występowali w wielu miastach. W Pekinie dwukrotnie polskie grupy teatralne wystawiały Dziady oraz Ziemię obiecana. W ostatnich trzech latach Krystian Lupa i Grzegorz Jarzyna podjęli się reżyserii sztuk inspirowanych literaturą chińską, mianowicie twórczością Lu Xuna i Shi Tieshenga, z chińską obsadą aktorską. Wszystkie te wydarzenia przyczyniły się do rozwoju wymiany kulturalnej między Polską a Chinami. Chińczycy kojarzą dziś Polskę nie tylko z Mikołajem Kopernikiem, Fryderykiem Chopinem i Marią Skłodowską-Curie,

2 Szczegółowe zestawienie utworów tłumaczonych w tym okresie na język chiński zawiera praca doktorska Li Yinan [2015: 49-50]. 
lecz także z wielkimi noblistami literackimi. Wiedzą doskonale, że już pięcioro polskich literatów uhonorowano Nagrodą Nobla.

Jako thumacz i badacz polskiej literatury studiowałem przed laty na Wydziale Polonistyki Uniwersytetu Warszawskiego. Obecnie pracuję w Instytucie Badań Literatury Obcej w Chińskiej Akademii Nauk Społecznych. Przełożyłem na chiński Dziady Adama Mickiewicza, Lalkę Bolesława Prusa, Quo vadis oraz Krzyżaków Henryka Sienkiewicza, a także wiele utworów poetyckich autorstwa dawnych mistrzów: Jana Kochanowskiego, Mikołaja Reja, Mikołaja Sępa Szarzyńskiego, Hieronima Morsztyna, Jana Andrzeja Morsztyna, Wacława Potockiego, Zbigniewa Morsztyna, Adama Naruszewicza, Ignacego Krasickiego, Adama Mickiewicza, Juliusza Słowackiego, Cypriana Kamila Norwida, oraz poetów współczesnych: Władysława Broniewskiego, Juliana Tuwima, Antoniego Słonimskiego, Brunona Jasieńskiego, Czesława Miłosza, Wisławy Szymborskiej, Tadeusza Różewicza, Mieczysława Jastruna, Zbigniewa Herberta, Adama Zagajewskiego, Ewy Lipskiej, Stanisława Barańczaka, Anny Kamieńskiej, Ernesta Brylla, Mirona Białoszewskiego, Stanisława Grochowiaka, Jerzego Jarniewicza, Alicji Mazan-Mazurkiewicz i in. Przetłumaczyłem również dwa polskie dramaty: Niemców Leona Kruczkowskiego oraz Dom pod Oświęcimiem Tadeusza Hołuja, a także prace estetyczne Romana Ingardena.

Za osiągniecia w przekładzie literatury polskiej na język chiński w roku 2000 otrzymałem, wraz z profesor Yi Lijun oraz profesorem Cheng Jizhongiem, Krzyż Kawalerski Orderu Zasługi RP za promocję kultury polskiej na świecie. W roku 2006 zostałem natomiast laureatem Złotego Medalu „Zasłużony Kulturze - Gloria Artis” przyznawanego przez Ministra Kultury i Dziedzictwa Narodowego RP.

Za najważniejsze moje dzieło uważam Historię literatury polskiej, której pisaniu poświęciłem aż osiem lat. Przygotowując się do tego zadania, przeczytałem ponad 1000 utworów literackich, a także wiele naukowych rozpraw polskich badaczy. Kilkukrotnie na zaproszenie Instytutu Książki w Krakowie uczestniczyłem w międzynarodowych konferencjach thumaczy literatury polskiej. Miałem wtedy również okazję zapoznać się z najnowszą polską twórczością. Historia ... przyczyniła się w znacznym stopniu do popularyzacji 
w Chinach twórczości Polaków. Jest to jedyny napisany po chińsku podręcznik omawiający tak kompleksowo dzieje literatury polskiej od średniowiecza do współczesności [Zhang 2017; 2018].

Historia literatury polskiej składa się z dwóch tomów zawierających dziewięć rozdziałów. Wszechstronnie przedstawia dzieje polskiej literatury od $\mathrm{x}$ wieku, czyli od momentu, kiedy zaczęło się kształtować państwo polskie, do czasów współczesnych. Każdy rozdział poświęcony jest jednej epoce literackiej. Pierwszy tom obejmuje epoki od średniowiecza do pozytywizmu, drugi zaś Młodą Polskę, dwudziestolecie międzywojenne, okres II wojny światowej oraz czasy powojenne. Nie tylko przedstawiam historię oraz zarys sytuacji społecznej, lecz także omawiam literackie prądy i kierunki oraz charakteryzuję twórczość najważniejszych literatów, uwzględniając walory ideowe oraz artystyczne ich dzieł. Podkreśliłem szczególną rangę twórczości Jana Kochanowskiego, Mikołaja Reja, Ignacego Krasickiego, Adama Mickiewicza, Juliusza Słowackiego, Zygmunta Krasińskiego, Cypriana Kamila Norwida, Henryka Sienkiewicza, Bolesława Prusa, Elizy Orzeszkowej, Marii Konopnickiej, Stefana Żeromskiego, Władysława Reymonta, Marii Dąbrowskiej, Jarosława Iwaszkiewicza, Czesława Miłosza, Wisławy Szymborskiej, Tadeusza Różewicza - tym twórcom poświęcone są osobne podrozdziały, gdyż ich dzieła cieszą się szczególnym zainteresowaniem wśród chińskich czytelników.

Ostatni podrozdział stanowi omówienie krytyki literackiej w Polsce. Szczególny nacisk kładę tam na teorie estetyki Romana Ingardena oraz Henryka Markiewicza. Zwłaszcza Ingarden, jako przedstawiciel szkoły fenomenologicznej, jest bardzo znany nie tylko na Zachodzie, lecz także w Chinach, m.in. dzięki mojemu przekładowi najważniejszej rozprawy tego filozofa - O dziele literackim. Przekład ten uzupełniłem w ostatnim czasie o tłumaczenia najważniejszych artykułów Ingardena dotyczących estetyki. Ukażą się one wkrótce w Chinach pt. Ingarden o literaturze.

Spośród polskich pisarzy najbardziej lubię Henryka Sienkiewicza, którego powieści mają niezwykłe walory artystyczne, oraz Bolesława Prusa, zwłaszcza Lalkę. Ta powieść przyniosła wszechstronny obraz XIX-wiecznej polskiej rzeczywistości, szczególnie w Królestwie Polskim i w Warszawie. Uważam, że Prus jest najwięk- 
szym polskim pisarzem realistycznym XIX wieku. Nie bez powodu znakomity polski socjolog Ludwik Krzywicki [1964: 171] pisal, że

jak Dickens w Anglii. Balzac we Francji, tak Prus u nas stanie się świadectwem, natury historycznej, świadectwem, które dalekim pokoleniom opowie, jak ludzie żyli życiem powszednim w Polsce w drugiej połowie wieku XIX.

Prus okazał się pisarzem nie tylko ponadczasowym, lecz także przekraczającym geograficzne granice. Dowodem na to jest uznanie, z jakim od dziesięcioleci spotyka się jego twórczość, w tym wspomniana wyżej Lalka, w Chinach - tak odmiennych, wydawałoby się, pod względem społeczno-politycznym i kulturowym od Polski.

Mój przekład Lalki, wysoko ceniony przez krytyków i czytelników, chińscy badacze literatury porównują z naszą najlepszą powieścią klasyczną z XVIII wieku: Snem czerwonego pawilonu (Hongloumeng) Cao Xueqina, prezentującą życie chińskiej arystokracji feudalnej. Wskazują, że dzieła te są wiernym odbiciem obrazu epoki obu krajów oraz ich społeczeństw.

Zajmuję się nie tylko tłumaczeniem literatury polskiej na chiński. Wiele lat poświęciłem również badaniom polskiej literatury. Opublikowałem monografie poświęcone życiu i twórczości Adama Mickiewicza, Henryka Sienkiewicza oraz Władysława Reymonta.

Oprócz przekładów literatury polskiej i badań nad nią bardzo interesuje mnie wymiana kulturalna między Polską a Chinami. Pierwszym Polakiem, który pojechał do Chin w celu lepszego poznania tego kraju, był jezuita Michał Boym. W połowie XVII wieku przybył na południe Chin i zaprzyjaźnił się z ostatnim cesarzem dynastii Ming. Napisał po łacinie wiele prac o chińskich zwyczajach, roślinności, geografii i chińskiej medycynie, wiernie odtworzył mapę Chin i jako pierwszy przedstawił Europie starożytną cywilizację chińską. Wszystkie jego prace na temat Chin przetłumaczyłem na język chiński wspólnie ze znanym polskim sinologiem Edwardem Kajdańskim. Całość wydana została w 2004 roku.

Później do Chin przyjeżdżało jeszcze wielu Polaków: Jan Mikołaj Smogulecki (1610-1656), Maurycy Beniowski (1746-1786), Fau- 
styn Ciecierski (1770-1832), Józef Kowalski (1800-1878), Agaton Giller (1831-1887), Jerzy Tymkowski (1790-1875), Paweł Piasecki (1843-1914), Władysław Michał Zaleski (1852-1925), Kazimierz Grochowski (1873-1937), Wacław Sieroszewski (1858-1945) i Witold Urbanowicz (1908-1996). Wszyscy oni podróżowali po Chinach, zawierali znajomości i przyjaźnie z ich mieszkańcami oraz pisali wspomnienia i pamiętniki na temat swoich wrażeń, chińskiej kultury, obyczajów i ekonomii. Wacław Sieroszewski jest nawet autorem powieści Diabet zamorski o chińskim XIX-wiecznym powstaniu bokserów skierowanym przeciwko kolonistom zachodnim. Powieść ukazuje chińską walkę narodowowyzwoleńczą. Witold Urbanowicz był z kolei bardzo zasłużonym lotnikiem walczącym w czasie wojny chińsko-japońskiej wspólnie z naszymi lotnikami. Ponadto król Jan III Sobieski, Ignacy Krasicki, Cyprian Kamil Norwid - mimo że nigdy nie byli w Chinach - również bardzo interesowali się kulturą chińską.

Obecnie mamy bardzo dobre warunki do wymiany kulturalnej między Polską a Chinami. Ja zaś planuję przetłumaczyć kolejne dzieła literatury polskiej na język chiński, aby nasi czytelnicy jeszcze lepiej poznali twórczość polskich pisarzy.

\section{Bibliografia}

Krzywicki Ludwik (1964), Maszyna do pisania, w: Parnas Polski we wspomnieniu i anegdocie: od Niemcewicza do Wyspiańskiego, oprac. Halina Przewoska, Stowarzyszenie Bibliotekarzy Polskich, Warszawa, s. 166-171.

Li Yinan (2015), Recepcja literatury polskiej w Chinach: wybrane zagadnienia, Uniwersytet Śląski w Katowicach, [rozprawa doktorska].

Lu Xun (1982), Moluo shi li shuo [O sile poezji Mara], Tianjin Renmin Chubanshe, Tianjin.

Yi Lijun (2010), Twórczość Henryka Sienkiewicza w Chinach, „Postscriptum Polonistyczne”, z. 2 (6), s. 97-107.

Zhang Zhenhui (2017), Bolan wenxue shi [Historia literatury polskiej], t. 1, Shanghai Waiyu Jiaoyu Chubanshe, Shanghai.

Zhang Zhenhui (2018), Bolan wenxue shi [Historia literatury polskiej], t. 2, Shanghai Waiyu Jiaoyu Chubanshe, Shanghai. 
Zhang Zhenhui

Polish Literature in China and Polish-Chinese Cultural Exchange. Translator's Notes

The article is an introduction into the presence of Polish literature in China from the perspective of one of its most active researchers and translators. The author describes his fascination with Bolesław Prus's work that resulted in the Chinese translation of Lalka (The Doll) and his work on two-volume Historia literatury polskiej (The history of Polish literature) aimed at Chinese readers.

Keywords: Polish literature in China; cross-cultural dialogue; literary translation; history of Polish literature; Lalka; The Doll.

Zhang Zhenhui - profesor, zasłużony badacz i tłumacz literatury polskiej. Jego dorobek obejmuje przekłady, m.in. Ziemi obiecanej Władysława Reymonta (wspólnie z Yang Deyou), Quo vadis Henryka Sienkiewicza czy poezji Wisławy Szymborskiej. Jest również autorem monografii poświęconych Henrykowi Sienkiewiczowi, Władysławowi Reymontowi, Adamowi Mickiewiczowi, a także chińskojęzycznej Historii literatury polskiej. 
